\title{
Bernardino Ramazzini (1633-1714): a visionary physician, scientist and communicator
}

\author{
F Carnevale, ${ }^{1}$ S lavicoli ${ }^{2}$
}

Three hundred years after his death, it is interesting to speculate how much this doctor from Carpi's talent for clinical innovation and communication still relates to modern occupational medicine. Bernardino Ramazzini insisted that progress in medicine should not focus solely on physiology and clinical questions, but should also cover the health of the population, observing any relations between environmental factors and disease. This approach, while influenced by the Hippocratic doctrine of 'airs, waters, places', also refers to the need to test new criteria for observation 'on the population', using new tools for processing and interpreting the findings. This surely demonstrates that this scholar from Carpi was very forward-looking indeed!

His De Morbis Artificum Diatriba [Diseases of Workers], first published in Modena in 1700 , reveals his forwardthinking ideas in its dedication to the Venetian reformers, laying the foundations for the social role of occupational medicine and hygiene, linking workers, business and political institutions. The treatise took at least 10 years to be conceived and written in the last decade of the 17th century. Ramazzini was 67 when he completed it, with more than 40 years of medical practice behind him, and in that very same year, at the peak of his fame, he was recognised by being called to the University of Padua. ${ }^{1}$

Ramazzini's talent is also clear from his ability to communicate and arouse his readers' interest, not only within the close circles of medicine but more broadly within the community. ${ }^{2}$ Like any great communicator in modern times, Ramazzini tells us that the idea of writing a treatise on workers' diseases came to him while

${ }^{1}$ Centro di documentazione storia sanità regione Toscana, Firenze, Italy; ${ }^{2}$ Department of Occupational and Environmental Medicine, Epidemiology and Hygiene, INAIL Research Area, Italian Workers Compensation Authority, Rome, Italy

Correspondence to Dr S lavicoli, Department of Occupational and Environmental Medicine,

Epidemiology and Hygiene, INAIL Research Area, Italian Workers Compensation Authority, Via Fontana Candida 1, Monteporzio Catone (Rome) I 00040, Italy; s.iavicoli@inail.it watching tradesmen emptying his cesspit at home. Ramazzini had the foresight to document the pairing of doctor and worker, partly because the time was ripe and partly because of his role in facilitating this pairing. He had a modern understanding that a social and economic change was under way and, as an example, in his De Morbis, he insisted that manual workers should be granted full 'rights of citizenship'.3

Ramazzini's communicating skills, however, go beyond the fact that he prompted far-reaching changes in occupational medicine. He complained that his colleagues, the physicians-but others too - did not show much interest or enthusiasm about his Treatise. So who was his 'audience'? ${ }^{4} \mathrm{He}$ identified his readers as an extended international community of intellectuals, influential people and advisers to princes. These were the people who made the decisions for their States, so that the social process got under way and took real form, acknowledging that workers and those managing public matters have certain interests in common - equivalent to the modern policymakers in occupational health.

In his construction and systematic organisation of the Treatise, Ramazzini demonstrated his advanced communication skills. The content of the chapters is presented following a fairly standard order of steps or constant elements. The body of each chapter consists of a review of the literature, most of it found in general medical texts written by other physicians. However, he also looked at works by chemists, 'sociologists' and even poets-a forerunner of today's interdisciplinary attitudes.

Ramazzini then goes on to lay out his observations like a classification of jobs, based on the paradigms of his own training, though he does not say so explicitly. This gives four main headings. The first heading groups the tasks that expose workers to diseases connected to handling or working with minerals and metals, or other raw materials extracted from the earth, while the second heading groups workers who absorb toxins by inhalation, from the air. The third heading deals with those activities

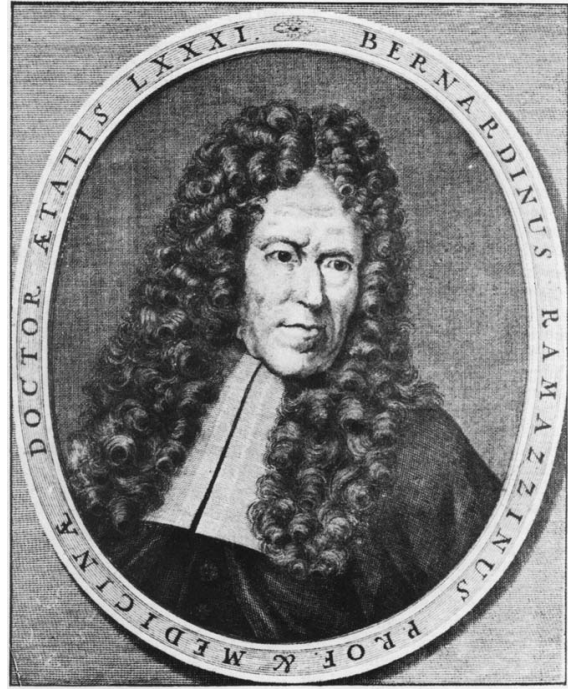

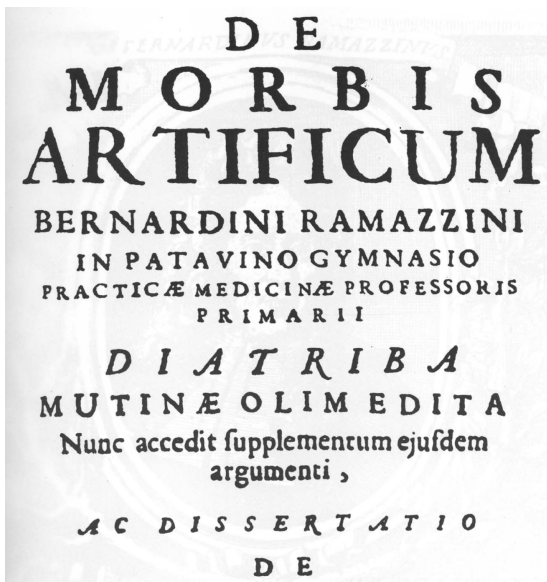

SA CR A R M VIRGINUM VALETUDINE TUENDA.

\section{PATAVII, M.DCC.XIII. Per Jo: Baptiftam Conzattum. \\ SVPER. PERM. AC PRIVIL.}

that expose workers to fluids such as water, milk and alcoholic beverages. The fourth, and last, heading comprises diseases due to unnatural postures or positions held for long periods. Ramazzini also showed considerable foresight in emphasising that the four categories that group workers presenting specific risk factors related to work are also linked-in some cases decisively-to the person's social status, current lifestyle habits or even those of the previous generations.

It has been claimed that, despite the lack of actual numbers, the chapters of De morbis were inspired by an attitude that was not sporadic but systematic, a forerunner of what we refer to today as epidemiology. ${ }^{5}$ Ramazzini's methodological 
approach is based on a process of deduction $^{6}$ which gives rise to his concept of 'occupational disease': one or more pathological conditions that gradually progress, usually swiftly, to a picture that is typical, specific and indissolubly linked to that particular task, sparing no one among its workers.

Ramazzini's concept of occupational disease is enough to brand him as an effective communicator, creator of images, icons and symbols. He forges an extremely evocative symbolic chain-a 'natural', cohesive link between the workshop, the worker and distress-disease-death; this symbiosis is unchangeable but can be adapted, acknowledged and, to some extent, controlled.

The workshop, the worker and the distress-disease-death chain comprise an evocative image to which Ramazzini applies the Renaissance lesson of perspective. This three-dimensional approach distinguishes the worker in the workplace, pointing more precisely to possible preventive measures or personal and environmental hygiene, in relation to the real toxic substances or products. This strategy can also be put to use in assigning the right proportion to an occupational component in the large numbers of persons whose poor health and physical weakness are likely to be influenced by poor hygiene, inadequate or inappropriate diet and living conditions, as well as work.

Ramazzini's principles have inevitably been picked up in more modern times by economists and politicians, and Ramazzini's concept of 'occupational diseases' has been extended. This started in the early decades of the 1800 s, almost in parallel in France and England, and has been projected in a fresh light by numerous historians in recent years. ${ }^{7}$ As the Age of Enlightenment gave way to the liberalism of the early 19th century, De morbis artificum diatriba took different paths in France, England and Germany, making the concept of 'craftsmen's diseases' obsolete ${ }^{8}$ in face of competition from the chemical industry ${ }^{9}$ and as countries moving towards industrialisation started showing increasing interest in minors and women as 'medicolegal' categories calling for protection before the others.

As we celebrate the 300th anniversary of the death of the doctor from Carpi, we can only admire his foresight. In today's world, with its economic and financial problems, globalisation of work and continual shifts in a $24 \mathrm{~h}$ cycle, Ramazzini offers us a highly topical lesson: medicine still merits a central place not only in debate in the scientific community, but above all in transferring scientific knowledge to policymakers.

Ramazzini's foresight lies primarily in his awareness of social change, his ability to pick out the possible stakeholders, and in selecting politicians as the 'model' target of De morbis. Although we can apply a sociological concept to the modern aspects of Ramazzini's Treatise, we can also detect the profile of the modern social researcher who moves beyond cultural and scientific interventions, extending his ethos to rights and policies, which was not accepted in the 17 th century but was to become accepted practice in the 20 th century. ${ }^{10}$

Three centuries after his death, Ramazzini is still an effective communicator, capturing the attention of the public with his work-which is notable for its literary value besides medical interestusing images that range from alarming, to rhetorical, ironic and theatrical, ${ }^{2}$ to convincingly communicate the dreadful conditions of workers, an approach which is still very relevant today.
Contributors The substantial contributions to the conception of this work was made by SI and FC and consisted in the bibliographical review and literature interpretation and revising it critically for important intellectual and drafting.

Competing interests None.

Provenance and peer review Commissioned; internally peer reviewed.

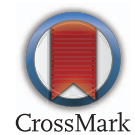

To cite Carnevale F, lavicoli S. Occup Environ Med 2015;72:2-3.

Received 3 December 2014

Accepted 5 December 2014

Occup Environ Med 2015;72:2-3.

doi:10.1136/oemed-2014-102744

\section{REFERENCES}

1 Di Pietro P. Bernardino Ramazzini, biography and bibliography. Eur J of Oncol 1999;4:253-317.

2 Turchi R. Bernardino Ramazzini medico-letterato. La Rassegna della Letteratura Italiana 2002;2:453-9.

3 Ramazzini B. Works. Caselle di Sommacampagna (Verona): Cierre Edizioni, 2012:13.

4 Eco U. A theory of semiotics. London: Macmillan, 1977.

5 Zocchetti C. Bernardino Ramazzini (1633-1714) Epidemiologo ante litteram. Epidemiologia e Prevenzione 2000;6:276-81.

6 Carnevale F, Mendini M, Moriani G. Introduction. In: Works. Caselle di Sommacampagna (Verona): Cierre Edizioni, 2012:15.

7 La Berge A. Mission and method, the earlynineteenth-century French public health movement. New York: Cambridge University Press, 1992;150-83.

8 Vincent J. Bernardino Ramazzini, historien des maladies humaines et médecin de la société civile? La carrière franco-britannique du De morbis artificum diatriba (1777-1855). In: Charle C, Vincent J, eds. La société civile. Savoirs, enjeux et acteurs en France et en Grande-Bretagne 1780-1914. Rennes, France: Presse Universitaire de Rennes, 2011:169-202.

9 Fressoz JB. Circonvenir les circumfusa, La chimie, l'hygiénisme et la libéralisation des "choses environnantes" France, 1750-1850. Revue d'Histoire Moderne et Contemporaine 2009;56:39-76.

10 Lush S. The sociology of postmodernism. London, England: Routledge, 1990:175. 